\title{
STUDIES ON LECTIN-INDUCED AGGLUTINATION OF DROSOPHILA EMBRYONIC CELL LINES
}

\author{
C. A. ANDREws and T. M. RIZKI \\ Division of Biological Sciences, The University of Michigan, Ann Arbor. \\ Michigan 48109. U.S.A
}

(Received 21 June 1977)

\begin{abstract}
The agglutination responses of three Drosophila cell lines to concanavalin A and wheat germ agglutinin have been examined. Although the cell lines were originally derived from late embryonic stages of the Ore- $R$ strain of Drosophila melanogaster, they show quantitative differences in lectininduced agglutination. Line 1 cells were least agglutinable with both lectins. All three cell lines reached maximum agglutination with concanavalin A concentrations at $25 \mu \mathrm{g} / \mathrm{ml}$, but the agglutination response to wheat germ agglutinin was biphasic such that an initial rapid increase in agglutination with concentrations up to $25 \mu \mathrm{g} / \mathrm{ml}$ was followed by slower agglutination above this concentration. Cells of lines 1 and 2 from ten-day old cultures exhibited greater lectin-induced agglutination than cells from threeday old cultures. Age-dependent differences were not found for line 3 cells which gave maximum agglutination responses in both young and old cultures. Cell agglutination by concanavalin $A$ was almost completely inhibited by pretreatment of the lectin with methyl- $\alpha$-D-mannopyranoside, but preincubation of wheat germ agglutinin with $N$-acetyl-D-glucosamine caused only partial blockage. Lectininduced agglutination was not reversible by treatment with the monosaccharide inhibitors. These observations have been discussed with reference to the origin of the three cell lines and their cell surface properties.
\end{abstract}

\section{INTRODUCTION}

Plant lectins have been used extensively to study surface properties of cultured cells since the binding of lectin molecules to specific receptor sites on the cell surface initiates an agglutination reaction. Among the lectins that have been utilized in agglutination tests, wheat germ agglutinin (WGA) shows a specificity for $N$-acetyl-D-glucosamine and concanavalin A (Con A) selectively binds with $\alpha$-D-glucose or $\alpha$-D-mannose derivatives. Generally, lower concentrations of lectins agglutinate virus-transformed and malignant cells than the concentrations required to agglutinate normal cells (AUB et al., 1963; BURGER and GolDBERG, 1967; INBAR and SACHS, 1969), and it is these differential responses of cells to lectin treatment that have prompted several hypotheses concerning cell surface architecture. BURGER's (1969) model proposes that agglutinin receptor sites are exposed in transformed cells whereas the receptor sites remain covered in normal cells. An alternate hypothesis suggests that differences in topographic distribution of lectin-binding sites on the cell surface may be related to agglutinability (NiCOLSON, 1974).

The major focus of attention in agglutination studies with WGA and Con A has been vertebrate cells. Recently, the response of Drosophila cells to lectins was examined, and both WGA and Con A induced fusion of the cells as well as agglutination (BECKER, 1972; RIZKI et al., 1975; HALFER and Petrella, 1976). These observations indicate that there may be cell surface differences between vertebrate and insect cells, since lectin-induced cell fusion has not been reported for vertebrate cells. The present study was therefore undertaken to examine lectininduced agglutination of Drosophila cells under conditions similar to those employed for vertebrate cells.

\section{MATERIALS AND METHODS}

Drosophila melanogaster cell lines 1, 2, and 3 were obtained from Dr. Imogene Schneider in September, 1972 , and have been maintained by weekly subculture in Schneider's medium (SCHNEIDER, 1964, 1966) supplemented with $15 \%$ heat-inactivated fetal calf serum (Rehatuin FS, Reheis Chemical Co.). Serum was tested and found to be free of bacterial virus contaminants according to the method of MERRIL et al. (1972) and Dr. T. B. Friedman (personal communication). The patterns of growth and morphology of the lines are similar to those originally described by SCHNEIDER (1972), although changes in karyotype have occurred (ANDREws, 1975). Cells were grown in glass T-15 flasks containing $1.5 \mathrm{ml}$ culture medium at $25^{\circ} \mathrm{C}$ with an initial inoculum of $1.0 \times 10^{6}$ cells per flask. Doubling times of lines 1,2 , and 3 were 19 to $20 \mathrm{hr}, 16 \mathrm{hr}$, and 19 to $20 \mathrm{hr}$ respectively.

The cells of lines 1 and 3 remain attached to the bottom of the flasks, whereas line 2 cells grow in suspension after the flask surface is covered with a monolayer of cells. Prior to harvesting cells of lines 1 and 3, they were rinsed three times with buffered saline solution (SEECOF, 1971) while they remained attached to the bottom of the flasks. The cells were then freed by gently flushing with a Pasteur pipette and suspended in saline solution at a concentration of $2.0 \times 10^{6} \mathrm{cells} / \mathrm{ml}$. Line 2 cells were concentrated by centrifugation. The pellet of cells was washed twice with saline solution and the cells were then resuspended in saline solution. This procedure was repeated and the cells were finally dispersed in saline solution at a concentration of $2 \times 10^{6}$ cells $/ \mathrm{ml}$. An aliquot of $0.1 \mathrm{ml}$ of cell suspension was used for each agglutination test.

Agglutination tests were performed at $25^{\circ} \mathrm{C}$ in one- 
dram shell vials with $0.1 \mathrm{ml}$ saline solution containing the appropriate concentration of WGA (Sigma Chemical Company) or Con A (Calbiochem). To each vial, $0.1 \mathrm{ml}$ of cell suspension was added. Controls vials contained $0.1 \mathrm{ml}$ of the cell suspension and $0.1 \mathrm{ml}$ saline solution. The vials were placed on a rotary shaker (based on the design of HENKART and HUMPHREYS, 1970) with a radius of gyration of $5 \mathrm{~cm}$. and rotated at $70 \mathrm{rev} / \mathrm{min}$. At the end of the treatment period, the number of residual single cells in each vial was counted with a hemacytometer. The per cent cell agglutination was calculated as: $(1-$ single cells in lectin-treated vial/single cells in control vial) $\times 100$. Agglutination was confirmed by observation with a phase contrast microscope. All values for agglutination reported in tabular form represent the averages of triplicate culture flasks from representative experiments.

The inhibitory effects of methyl- $\alpha-D-m a n n o p y r a n o-$ side (MMP) and $N$-acetyl-D-glucosamine (NAGlu) on lectin-induced agglutination were studied by preincubating the inhibitors and lectins in saline solution for at least five minutes before the addition of cells. The mixtures were then rotated, and the cells counted as described above to determine the per cent agglutination.

\section{RESULTS}

Figure 1 summarizes the agglutination responses of the three cell lines as a function of lectin concentration. Agglutination of the cells of all three lines was maximal at a Con $A$ concentration of approximately $25 \mu \mathrm{g} / \mathrm{ml}$. However, differences among the three lines were apparent in the initial rise of the curves as well as the levels of agglutination achieved by $25 \mu \mathrm{g} / \mathrm{ml}$ Con A. Approximately $95^{\circ} \%$ of the line 3 cells were agglutinated by the Con A treatment whereas only $55 \%$ of the line 1 cells were clumped by this same experimental procedure.

The response to WGA also revealed differences among the cell lines and, as in the case with Con A, fewer line 1 cells were agglutinated (Fig. 1). There was, however, a biphasic agglutination response to WGA with the amount of agglutination increasing rapidly up to a concentration of approximately 25 $\mu \mathrm{g} / \mathrm{ml}$ and less rapidly above this concentration.

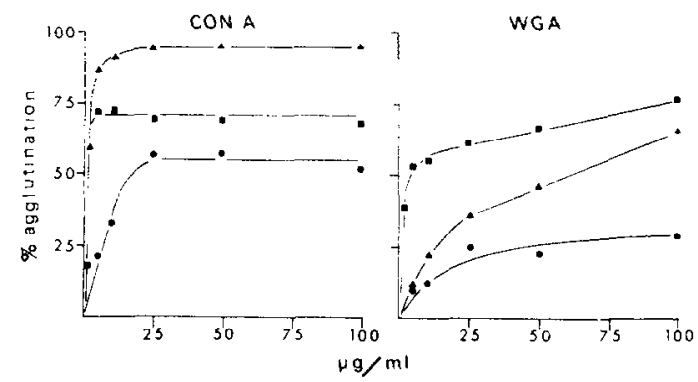

Fig. 1. Agglutination as a function of lectin concentration. Each point represents a single determination taken after $5 \mathrm{~min}^{4}$ reaction of cells and lectins. Cells were obtained from parallel 10-day cultures of line $1(\mathbf{C})$, line $2(\square)$, and line $3(\mathbf{A})$.

To determine whether culture age affects agglutination responses, cells were harvested for agglutination on days three and ten after subculture, and subjected to the agglutination reaction for five minutes with $100 \mu \mathrm{g} / \mathrm{ml} \mathrm{Con} \mathrm{A}$, a concentration assuring maximum agglutination. The cells of lines 1 and 2 from ten-day cultures exhibited greater agglutination than did cells from three-day cultures while line 3 cells showed maximum agglutination at both ages (Table 1). The effect of culture age on cell agglutination induced by WGA was also examined in a similar series of experiments using two concentrations of WGA. Again, the percentage of cells agglutinated in ten-day cultures of lines 1 and 2 was higher than that in three-day cultures (Table 1) whereas line 3 cells showed no change in agglutination with culture age. These data on WGA agglutination also confirm the observations depicted in Fig. 1 by showing that increased agglutination of the cells was obtained when the WGA concentration was raised to $500 \mu \mathrm{g} / \mathrm{ml}$. The increase in agglutination observed with a WGA concentration of $500 \mu \mathrm{g} / \mathrm{ml}$ as compared to $100 \mu \mathrm{g} / \mathrm{ml}$ was significant at the 0.05 level in all instances except for line 1 cells from three-day cultures which showed about five per cent agglutination at both concentrations.

Preincubation of Con A with 0.1 M MMP, a monosaccharide which Con A reportedly binds (GOLDSTEIN et al., 1965), almost completely inhibited the agglutination of the cells of the three lines by Con A (Table 2). The agglutination of all three cell

Table 1. Effect of culture age and lectin concentration on agglutinability

\begin{tabular}{lcccc}
\hline & $\begin{array}{c}\text { Culture } \\
\text { age } \\
\text { (days) }\end{array}$ & $\begin{array}{c}\text { Con A } \\
100 \mu \mathrm{g} / \mathrm{ml}\end{array}$ & $100 \mu \mathrm{g} / \mathrm{ml}$ & WGA \\
\hline Line 1 & 3 & $35.6 \pm 2.8$ & $5.7 \pm 6.7$ & $6.2 \pm 6.3$ \\
& 10 & $79.4 \pm 4.9$ & $57.5 \pm 6.8$ & $73.8 \pm 5.2$ \\
Line 2 & $\overline{\mathrm{X}}_{10}-\overline{\mathrm{X}}_{3}$ & $43.8^{*}$ & $51.8^{*}$ & $67.6^{*}$ \\
& 10 & $60.9 \pm 3.3$ & $67.2 \pm 5.0$ & $85.6 \pm 3.2$ \\
Line 3 & $\overline{\mathrm{X}}_{10}-\overline{\mathrm{X}}_{3}$ & $89.5 \pm 1.6$ & $85.9 \pm 2.9$ & $92.7 \pm 0.1$ \\
& 3 & $28.6^{*}$ & $18.7^{*}$ & $7.1^{*}$ \\
& 10 & $94.7 \pm 1.1$ & $60.9 \pm 2.7$ & $92.9 \pm 2.6$ \\
& $\overline{\mathrm{X}}_{10}-\overline{\mathrm{X}}_{3}$ & $94.4 \pm 0.7$ & $68.0 \pm 6.3$ & $89.0 \pm 2.2$ \\
\hline
\end{tabular}

Cell agglutination was scored after 5 min of reaction with lectins. The mean \pm S.D. values are based on three samples, each taken from an independent culture. *indicates the differences between means $\bar{X}_{10}-\bar{X}_{3}$ are significant at $\propto 0.05$. The increased agglutination with $500 \mu \mathrm{g}$ WGA is statistically significant in all cases except for line 1, 3-day old cultures. 
Table 2. Blockage of lectin activity by monosaccharides: methyl- $x$-D-mannopyranoside (MMP) and $N$-acetyl-D-glucosamine (NAGlu)

\begin{tabular}{|c|c|c|c|c|}
\hline & \multicolumn{2}{|c|}{ Con $\mathrm{A}$} & \multicolumn{2}{|c|}{ WGA } \\
\hline & $100 \mu \mathrm{g} / \mathrm{ml}$ & $\begin{aligned} & 100 \mu \mathrm{g} / \mathrm{ml} \\
+ & 0.1 \mathrm{M} \mathrm{MMP}\end{aligned}$ & $100 \mu \mathrm{g} / \mathrm{ml}$ & $\begin{aligned} & 100 \mu \mathrm{g} / \mathrm{ml} \\
+ & 0.1 \mathrm{M} \mathrm{NAGlu}\end{aligned}$ \\
\hline Line 1 & $81.2 \pm 3.5$ & $1.3 \pm 6.9$ & $60.9 \pm 3.1$ & $44.8 \pm 6.9$ \\
\hline Line 2 & $85.9 \pm 1.0$ & $3.3 \pm 3.4$ & $88.0 \pm 3.1$ & $77.9 \pm 5.4$ \\
\hline Line 3 & $94.6 \pm 1.1$ & $1.5 \pm 1.4$ & $72.1 \pm 7.2$ & $27.9 \pm 6.9$ \\
\hline
\end{tabular}

Lectins were incubated with MMP or NAGlu for $5 \mathrm{~min}$. Cells were then added and agglutination was scored after 5 min' reaction. The mean \pm S.D. in each case is based on three samples from independent cultures. All differences between agglutination values of control and monosaccharide treated lectins are statistically significant at $\subsetneq 0,05$.

lines was also inhibited by preincubation of WGA with $0.1 \mathrm{M}$ of the monosaccharide it binds, NAGlu (BURGER and GoldBerg. 1967), but to a lesser extent than that obtained in the Con A experiments. When the cells were first agglutinated by Con A or WGA, the agglutination was not reversed by the addition of $0.1 \mathrm{M}$ MMP or NAGlu respectively, even after several hours of incubation.

\section{DISCUSSION}

The experiments involving the agglutination response of Schneider's Drosophila cell lines as a function of Con A concentration show that the rank order of the three lines is line $3>$ line $2>$ line 1 ; for the WGA response, the rank order is line $2>$ line $3>$ line 1 . The fact that the two rank orders differ suggests that there are quantitative differences in the binding sites for the two lectins among the three cell lines. An additional discrimination between the cell lines can be generated if the agglutination response is examined as a function of subculture age. The lectin-mediated agglutination of the cells from ten-day cultures of lines 1 and 2 was higher than that from three-day cultures whereas line 3 cells showed maximum agglutination in both young and old cultures (Table 1). The differences between the agglutination values of young and old cultures of line 1 , however, were higher than the differences for line 2.

The increased lectin-induced agglutination observed in older Drosophila cell cultures implies a change in cell surface properties as the cultures age. Agglutinability of other cell types by lectin treatment is also influenced by culture age (BEN-BASSAT et al., 1971: NoONAN and BURGER, 1973) and, in this respect, the behavior of these insect cells is comparable to that of transformed vertebrate cells, suggesting generalized age-dependent effects on cell surface. That the surface features of Drosophila cells change with increasing culture age has been verified by examination of Schneider's cell lines with the scanning electron microscope (RIZKI et al., in preparation). These changes are especially pronounced for line 1 cultures in which the cells form colonies on the substratum. In small colonies of young cultures the cells have a smooth surface texture whereas many of the cells in large colonies of older cultures possess numerous microvilli. An increase in surface area concomitant with development of microvilli and other surface projections suggests exposure of additional lectin-binding sites for cell-cell interactions, so the age-associated surface differences correlate well with the observed age-dependent agglutination responses for this line. Alternately, the same number of binding sites in sur- faces covered by microvilli might provide better mechanical strength to cell-cell interactions due to interdigitation of the microvillar surfaces with bivalent Con A molecules. In this case. microvillar morphology would have an additive effect on cell clumping. The correlation between microvillar surfaces and the cell agglutination response is also consistent with the observations on line 3 cells. Line 3 cells are covered with numerous microvilli in both young and old cultures, and this line shows high agglutination responses to Con $A$ and WGA at both ages. On the other hand, line 2 cells are relatively smooth-textured and pronounced differences in surface topography between two- and seven-day cultures were not observed. The three-day cell cultures of this line showed a higher agglutination response to Con $\mathrm{A}$ than the three-day line 1 cells which are also smoothsurfaced, suggesting that initially line 2 cells may have more binding sites than line 1 cells. The contribution of microvilli to agglutination can be assessed by comparing the relative increases in agglutination within the two lines. Agglutination of line 1 cells by Con A shows a $45^{\circ}$, difference between day 3 and day 10 while line 2 shows a difference of $25^{\circ}$, within the same interval. Compared in this way, we might assign the additional increase $\left(45^{\circ}{ }_{0}-25^{\circ}{ }_{0}=20_{0}^{\circ}\right)$ in agglutination of line 1 to the development of microvilli and surface projections.

Another possible explanation for age-dependent effects on cell agglutination is suggested by the fact that dividing cells in these lines are insensitive to membrane perturbations normally induced by Con A and WGA (RIZKI et al., 1975; RIZKI et al., in preparation). One might expect, therefore, that a sample of cells from a culture in the log phase of growth would exhibit less agglutination than a population derived from older cultures. The final level of cell clumping attained for a given lectin treatment will be influenced by a number of factors that relate to the distribution of lectin-binding sites on the cell surface. NiCOLSON (1974) has evaluated the rôles of cell surface and membrane structure in lectin-induced agglutination, but it should be stressed that cell fusion was not observed in the studies on which his discussions were based. Consideration of the factors that affect clumping of Drosophila cells must account for the aggregation of at least some of the cells by this process (BECKER, 1972; RizKI et al., 1975: HALFER and Petrella, 1976)

The biphasic nature of the agglutination response of the cells of Schneider's Drosophila lines to WGA suggests a heterogeneity of cell surface binding sites for this lectin whereas Con A binding sites appear to be uniform and saturable at concentrations ahen: 
$25 \mu \mathrm{g} / \mathrm{ml}$. WGA specifically binds NAGlu but has been shown to bind with greater affinity to its diand trisaccharides (ALLEN et al., 1973; NAGATA and BURGER, 1974; GoldSTEIN et al., 1975). In addition, GREENAWAY and LEVINE (1973) reported nonspecific binding of WGA to sialic acid, so a number of factors may influence cell agglutination by WGA. The observation that cell agglutination by WGA was decreased in the presence of NAGlu but not completely inhibited also supports the contention that binding of WGA to the Drosophila cell surface may not be limited to NAGlu sites. On the other hand, Con A-induced agglutination of Drosophila cells was blocked by pretreatment of this lectin with its specific inhibitor, MMP. These results are consistent with those of RizKI et al. (in preparation) who observed that Con A-induced fusion of the cells of Schneider's Drosophila lines was prevented by MMP whereas WGA-induced fusion was not inhibited by NAGlu (RIzKI et al., 1975). It appears that WGA has a greater affinity for receptor sites on Drosophila cell surfaces than it does for NAGlu. The Con A- and WGAinduced cell fusion reported by RIzKI et al. (1975) is also supported in the present study by the inability of monosaccharide hapten inhibitors to reverse lectininduced agglutination.

SCHNEIDER's (1972) cell lines were derived from 20 to $24 \mathrm{hr}$ old embryos, so the tissue of their origin is unknown. During the primary culture phase of line 3. cell masses were transplanted into host larvae that subsequently metamorphosed and the implants that had differentiated as adult structures were recovered. Therefore, line 3 probably originated from imaginal disc cells. A similar test was not performed with lines 1 and 2 , but spheres from other primary cultures that were tested in this manner underwent differentiation to give adult tissues, so Schneider assumed that the other two lines were also derived from imaginal discs. This potential, however was no longer demonstrable after subculture (SCHNEIDER, 1972; DüBENDORFER and SHIELDS, 1972). More recently, ILLMENSEE (1976) tested the potentiality of the nuclei from the three cell lines to promote differentiation. He found that line 2 nuclei still retain the potential to differentiate larval tissues whereas line 1 nuclei can contribute to the differentiation of both larval and adult tissues. No tissues were derived from line 3 donor nuclei. It seems that the three cell lines had different embryonic origins or the lines have digressed during culture in vitro. SCHNEIDER (1972) noted differences in the morphological and growth characteristics of the three cell lines. The present study indicates additional distinctive features of the three lines; these differences revealed by the use of lectins must relate to the cell surface architecture and the prevalent determined state of the cells

Acknowledgements-This investigation was supported by Grants CA-16619 and CA-12600 from the National Cancer Institute, DHEW and NIH Biomedical Sciences Grant RR-07050. C. A. Andrews received support from Training Grant No. 5T01-GM-71-17. We are grateful to Dr. I. SCHNEIDER for providing the Drosophila cell lines and for advice on the maintenance of Drosophila cells in vitro.

\section{REFERENCES}

Allen A. K., Neuberger A., and Sharon N. (1973) The purification, composition and specificity of wheat germ agglutinin. Biochem. J. 131, 155-162.
ANDREws C. A. (1975) Surface properties and carbohydrate metabolism of cells of Drosuphila melanogaster grown in vitro. $\mathrm{Ph} . \mathrm{D}$. thesis. The University of Michigan. Ann Arbor.

Aub J. C., Tieslau C. and Lankester A. (1963) Reactions of normal and tumor cell surfaces to enzymes, I. Wheatgerm lipase and associated mucopolysaccharides. Proc. natn. Acad. Sci. U.S.A. S0, 613-619.

BECKER M. J. (1972) Fusions in vitro de cellules somatiques en culture de Drosophila melanogaster, induites par la Concanavaline A. C.R. Acad. Sci., Paris 275, 2969-2972.

Ben-Bassat H., InbaR D. M., and SaCHS L. (1971) Changes in the structural organization of the surface membrane in malignant cell transformation. J. Membrane Biol. 6, 183-194.

BURGER M. M. (1969) A difference in the architecture of the surface membrane of normal and virally transformed cells. Proc. natn. Acad. Sci. U.S.A. 62, 994-1001.

Burger M. M. and Goldberg A. R. (1967) Identification of a tumorspecific determinant on neoplastic cell surfaces. Proc. nat. Acad. Sci. U.S.A. 57, 359-366.

DÜBendORFER A. and SHIEldS G. (1972) Proliferation in vitro and in vivo of a cell line originally derived from imaginal disc cells. Drosophila Infor. Serv. 49, 43.

Goldstein I. J., Hammarstrom S., and Sundblad G. (1975) Precipitation and carbohydrate-binding specificity studies on wheat germ agglutinin. Biochim. Biophys. Acta 405, 53-61.

Goldstein I. J., Hollerman C. E., Smith E. E. (1965) Protein-carbohydrate interaction. II. Inhibition studies on the interaction of concanavalin $\mathrm{A}$ with polysaccharides. Biochemistry 4, 876-883.

Greenaway P. J. and LeVine D. (1973) Binding of $N$-acetyl-neuraminic acid by wheat-germ agglutinin. Nature. New Biology 241, 191-192.

Halfer C. and Petrella L. (1976) Cell fusion induced by lysolecithin and concanavalin $\mathrm{A}$ in Drosophila melanogaster somatic cells cultured in vitro. Exp. Cell Res. 100, 399-404.

Henkart P. and Humphreys T. (1970) Cell aggregation in small volumes on a gyratory shaker. Exp. Cell Res. 63, 224-227.

ILLMENSEE K. (1976) Nuclear and cytoplasmic transplantation in Drosophila. In Insect Development (Ed. LAWRENCE P. A.) Blackwell Scientific Publications, Oxford.

INBAR M. and SACHS L. (1969) Interaction of the carbohydrate-binding protein concanavalin $\mathrm{A}$ with normal and transformed cells. Proc. nat. Acad. Sci. U.S.A. 63, $1418-1425$.

Merril C. R., Friedman T. B., Attallah A. F. M., Geier M. R., KRELL K., and Yarkin R. (1972) Isolation of bacteriophages from commercial sera. In vitro 8, 91-93.

NAGATA Y. and BURGer M. M. (1974) Wheat germ agglutinin. Molecular characteristics and specificity for sugar binding. J. biol. Chem. 249, 3116-3122.

NicolsoN G. L. (1974) The interactions of lectins with animal cell surfaces. Int. Rev. Cytol. 39, 89-190.

NoONAN K. D. and BURGer M. M. (1973) The relationship of concanavalin A binding to lectin-initiated cell agglutination. J. Cell Biol. 59, 134-142.

Rizki R. M., RIZKI T. M., and ANDREws C. A. (1975) Drosophila cell fusion induced by wheat germ agglutinin. J. Cell Sci. 18, 113-121

SCHNEIDER I. (1964) Differentiation of larval Drosophila eye-antennal discs in vitro. J. exp. Zool. 156, 91-104.

SCHNEIDER I. (1966) Histology of larval eye-antennal disks and cephalic ganglia of Drosophila cultured in vitro. J. Embryol. exp. Morph. 15, 271-279.

SCHNEIDER I. (1972) Cell lines derived from late embryonic stages of Drosophila melanogaster. J. Embryol. exp. Morph. 27, 353-365.

SEECOF R. L. (1971) Phosphate-buffered saline for Drosophila. Drosophila Infor. Serv. 46, 113. 